\title{
Absorption and sorptivity of cover concrete
}

\author{
Claisse, P.A. , Elsayad, H.I. and Shaaban, I.G.
}

See version note below, deposited in CURVE May 2014

Original citation \& hyperlink:

Claisse, P.A. , Elsayad, H.I. and Shaaban, I.G. (1997) Absorption and sorptivity of cover concrete. Journal of Materials in Civil Engineering, volume 9 (3): 105-110.

http://dx.doi.org/10.1061/(ASCE)0899-1561(1997)9:3(105)

Version note:

This is the author's version of the journal article, it is not known whether this version is before or after the peer review process.

Copyright (C) and Moral Rights are retained by the author(s) and/ or other copyright owners. A copy can be downloaded for personal non-commercial research or study, without prior permission or charge. This item cannot be reproduced or quoted extensively from without first obtaining permission in writing from the copyright holder(s). The content must not be changed in any way or sold commercially in any format or medium without the formal permission of the copyright holders.

This document is the author's version of the journal article; it is not known whether this version incorporates any revisions agreed during the peer-review process. Some differences between the published version and this version may remain and you are advised to consult the published version if you wish to cite from it.

CURVE is the Institutional Repository for Coventry University http://curve.coventry.ac.uk/open 


\title{
ABSORPTION AND SORPTIVITY OF COVER CONCRETE Peter A Claisse ${ }^{1}$, Hanaa I Elsayad ${ }^{2}$ and Ibrahim G Shaaban ${ }^{3}$
}

\begin{abstract}
The absorption characteristics and sorptivity of cover concrete obtained by the Initial Surface Absorption Test (ISAT), the Covercrete Absorption Test (CAT) and the sorptivity test have been studied and compared. Two types of concrete, namely OPC control and Low Water Concrete (LWC) of grade 35 have been tested. The laboratory work has shown close agreement between the ISAT and sorption results but the CAT yields higher results. An analytical model has been developed based on the mechanisms of capillary suction and pressure driven flow. In this model water entering concrete during the tests is assumed to be concentrated in a well defined volume. This volume is fully saturated and is separated from the surrounding concrete by a wetting front at which capillary suction occurs. By applying the physical equations for capillary suction pressures and permeability the experimental results are explained in terms of the basic properties of the concrete. The model gives good agreement with the experimental results.
\end{abstract}

\section{KEYWORDS}

Concrete, Durability, Testing, Absorption, Capillary suction, Transport properties.

1 Senior lecturer, School of The Built Environment, Coventry University, Priory Street, Coventry CV1 5FB, UK.

2 Lecturer, Faculty of Engineering, Fayoum, Cairo University, FAYOUM, EGYPT.

3 Lecturer, Faculty of Engineering, Shoubra, Zagazig University (Banha Branch), SHOUBRA, CAIRO, EGYPT 


\section{INTRODUCTION}

The deterioration of concrete usually involves movement of aggressive gases and/or liquids from the surrounding environment into the concrete followed by physical and/or chemical reactions within its internal structure, possibly leading to irreversible damage. Therefore, the transport properties, rather than the mechanical properties, are the important factors for concrete durability. With superstructures subject to a cyclic wetting and drying regime, the capillary suction forces (absorptivity properties) are responsible for the ingress of contaminated water through the cover concrete. Therefore, reliable assessment of absorption characteristics of cover concrete is essential.

A number of absorption tests have been reported in the literature (Basheer et.al. 1993, Concrete Society, 1984 and Bungey, 1989). Some of these tests are applicable only in the laboratory, e.g. Sorptivity Test (Hall, 1989), whilst others are used both in the laboratory and on site, e.g. Initial Surface Absorption Test, ISAT (Levitt, 1969), and Cover Concrete "Covercrete" Absorption Test, CAT, (Dhir et.al. 1987). In spite of the large amount of research involved in developing new tests to evaluate the concrete quality, little effort has been made towards comparing these tests and their results (e.g. Hall, 1989 and Price and Bamforth 1993). For example, ISAT and CAT both study the water absorption of concrete using similar techniques and yielding permeation characteristics with identical units of measurement. However, there is no indication why CAT always produces higher values than ISAT. On the other hand, in spite of the fact that ISAT and sorptivity test are measuring absorption properties, each of them indicates the absorption with different parameters. As a result, no quotation can be made for an absolute value of concrete absorption.

The objective of this paper is to improve the understanding of the absorption mechanism by comparing the sorptivity test and CAT results with ISAT (the most used method for the 
determination of absorption on site, (Concrete Society, 1984)), using samples of different mixes and curing conditions.

\section{BACKGROUND TO THE ABSORPTION TESTS}

\section{Initial Surface Absorption Test (ISAT)}

The test method was developed first by Levitt (1969) as a quality control test for precast concrete units. It is described in detail in BS 1881: Part 5 (1970). Modifications for the test apparatus were made by Dhir et al (1987 and 1991) in order to make it more accurate and easier to use. A cap of known area is clamped to the test surface, two pipes lead from the cap with one acting as a reservoir, which can be isolated by a tap. The other is connected to a calibrated capillary tube, to measure the rate of absorption of water into the concrete below the cap on closure of the tap (see Figure 1).

The initial surface absorption (ISA) is defined as the rate of flow of water (under a constant applied pressure and temperature) into concrete per unit area at stated intervals from the start of the test. The theory is based on the assumption that dried concrete absorbs water by capillary action at a rate which is initially high but decreases as the water filled volume of capillaries increases, Levitt (1969) derived the mathematical formula from the Pouseille equation for a liquid travelling through a single capillary tube, expressed in MKS units as:

$$
I S A=\frac{F}{\Theta}=a t^{-n}
$$

where:

$$
\begin{aligned}
\text { ISA } & =\text { initial surface absorption }\left(\mathrm{m}^{3} / \mathrm{m}^{2} / \mathrm{s}\right) \\
\mathrm{t} & =\text { absorption time }(\mathrm{s}) \\
\mathrm{a}, \mathrm{n} & =\quad \text { regression parameters. } \\
\theta & =\text { Area under cap }\left(\mathrm{m}^{2}\right)
\end{aligned}
$$




$$
\mathrm{F} \quad=\quad \text { Flow rate }\left(\mathrm{m}^{3} / \mathrm{s}\right)
$$

\section{Cover Concrete "Covercrete" Absorption Test (CAT)}

Dhir et al (1987) developed a method to test the absorption characteristics over the full depth of a $50 \mathrm{~mm}$ hole drilled in the cover concrete. The CAT method has the advantage of not being influenced by very localised surface effects such as carbonation of the outer few millimetres of the concrete. A hole of $13 \phi \times 50 \mathrm{~mm}$ is drilled on one of the surfaces (not the cast surface). A basic ISAT set-up is used but with a $13 \mathrm{~mm}$ internal diameter cap. An inlet tube located inside the sealed hole is used to supply water to the concrete test cavity as shown in Figure 2. The procedure of carrying out CAT is the same as that for ISAT. The results are normally quoted as a flow per unit area where the area is the surface of the drilled hole.

\section{The Sorptivity Test}

The sorptivity test was carried out as shown in Figure 3 (Hall, 1989). Hall defined the sorptivity as the slope of the cumulative volume of water absorbed per unit area against the square root of time:

$$
\frac{1}{\Theta} \int F d t=S t^{1 / 2}
$$

where:

$$
\mathrm{S} \quad=\quad \text { the sorptivity }
$$

Hall related the ISA at 10 minutes (ISA 10 ) to sorptivity $(S)$ empirically as $S=0.455$ ISA $_{10}$, where $\mathrm{s}$ is in $\mathrm{mm} / \mathrm{min}^{0.5}$ and $\mathrm{ISA}_{10}$ in $\mathrm{ml} / \mathrm{m}^{2} / \mathrm{s}$. 


\section{EXPERIMENTAL DETAILS}

\section{Preparation of Test Samples}

Two concrete types, namely, OPC control and low water concrete (LWC) of grade 35 were tested (Table 1). The test specimens (dimensions are detailed in each test procedure) were cast and kept under wet hessian for 1 day before demoulding. Two curing conditions were used: water curing at $20^{\circ} \mathrm{C}$ and air curing at $20^{\circ} \mathrm{C}, 55 \% \mathrm{RH}$, until testing at 28 days. The tests were carried out on duplicate specimens.

\section{Procedures}

(a) Measurements of ISAT were carried out using samples (100 mm cubes) preconditioned in the oven at $105^{\circ} \mathrm{C}$ until constant weight. To simulate a undirectional flow, ISAT specimens were $100 \mathrm{~mm}$ cubes and the surface portion, not under the ISAT cap was coated with grease. The initial surface absorption (ISA) was recorded at $10,30,60$ and 120 minutes.

(b) CAT results were obtained in the same way as ISAT using $100 \mathrm{~mm}$ cubes conditioned in the oven exactly as for the ISAT samples.

(c) Measurements of water sorptivity were carried out using specimens $(50 \phi \times 150 \mathrm{~mm})$ oven dried to the same conditions as ISAT samples and then rested on rods in water containers to allow free access of water to the inflow surface (see Figure 3). The water level was maintained to remain at no more than about $5 \mathrm{~mm}$ above the base of the specimens. The lower areas on the sides of the specimens were coated with grease to achieve uni-directional flow. The cumulative water absorbed was recorded at different time intervals up to 2 hours by weighing the specimen after removing the surface water using a dampened tissue. 
(d) A series of tests were carried out on concrete cubes in order to assess the shape of the wetting front after ISAT and CAT applications. This was done by splitting the test specimens at different intervals of time (e.g. 10,30,60 and 120 min) to observe the depth and width of water penetration.

(e) The intrinsic permeability of the samples was measured with water. This was carried out using a modified "Hoek" triaxial cell. In this cell $55 \mathrm{~mm}$ diameter cores approximately $50 \mathrm{~mm}$ long were contained using hydraulic pressure on the curved surfaces and water was pumped through the lower flat surface under a pressure of approximately $7 \mathrm{MPa}$. The flow rate was measured after the system had reached equilibrium.

\section{RESULTS AND DISCUSSION}

\section{Preliminary Analysis}

The relationships between ISA, CAT and time followed equation (1) with a high correlation coefficient $(\mathrm{r}=0.99)$. In order to compare the results from the different experiments it was necessary to express the absorption results in differential form. If the flow rate is assumed to be of the same form as equation (1) this may be integrated to give the measured weight gain of the form:

$$
\int F d t=\frac{\Theta a t^{(1-n)}}{1-n}
$$

The absorption results showed a high correlation with this equation and results for a and $\mathrm{n}$ were obtained. The results for a and $\mathrm{n}$ from each of the three tests are given in Table 2 . 
It may be seen that there is excellent agreement between the absorption results and the ISAT results and higher flow rates for the CAT. This is in agreement with the literature (Dhir et.a1. 1987).

The type and curing of concrete has a significant influence on the depth of water penetration. Typical wetting front shapes for ISAT and CAT applications for water cured concrete of grade 35 are shown in Figure 4. It can be seen that the wetting front shape is parabolic with a wide base on the concrete surface. This is attributed to the fact that the skin layer is more porous (due to bleeding channels, entrapped air, aggregate settlement... etc).

\section{The General Model}

There are numerous mechanisms which may contribute to the movement of water through concrete including pressure driven flow (permeation), capillary suction, osmosis, electroosmosis and thermal migration. For simplicity this model assumes that the flow is driven by capillary suction. This will create a pressure:

$$
P=\frac{2 s}{r}
$$

where:

$S$ is the surface tension of the water in $\mathrm{N} / \mathrm{m}$

and

$r$ is the radius of the pores in $m$

(the $200 \mathrm{~mm}$ head of water in the ISAT and CAT tests is assumed to be substantially less than P)

In the model it is assumed that, at any given time $t$ after the start of the test, a volume $\mathrm{V}$ of the concrete is saturated with water and there is no water outside it. This assumption of a 
well defined front to the water penetration is in agreement with the observations on samples which had been broken open during the test. Thus:

$$
F=\alpha \frac{d V}{d t}
$$

where $\alpha$ is the porosity

The flow through the concrete to the penetration front will be limited by the permeability. Thus (Darcy 1856):

$$
F=\frac{K \theta}{E} \frac{d p}{d x}
$$

where :

$\mathrm{K}$ is the intrinsic permeability in $\mathrm{m}^{2}$

$\mathrm{E}$ is the viscosity of the water in $\mathrm{Pa} \mathrm{s}$

$\mathrm{p}$ is the pressure in $\mathrm{Pa}$ at a distance $\mathrm{x} \mathrm{m}$ from the water reservoir.

$\theta$ is the area in $\mathrm{m}^{2}$ across which the water is flowing.

\section{Applying the model to ISAT and Absorption}

Considering initially the absorption test and the ISAT for which the flow may be considered as one dimensional (i.e. the curved wetting front in fig. 4 is assumed to be flat). The area is constant thus from equations (4) and (6):

$$
F=\frac{K \Theta}{E} \frac{P}{X}=\frac{2 s K \Theta}{E r X}
$$

where: 
$\mathrm{X}$ is the distance in $\mathrm{m}$ from the reservoir to the wetting front.

and

$\theta$ is the constant area.

Also:

$$
V=X \Theta
$$

Differentiating equation (7) with respect to $t$ and combining it with equations (5) and (8) gives:

$$
\begin{aligned}
& F=\beta \frac{d}{d t}\left(\frac{1}{F}\right) \\
& \text { where } \\
& \beta=\frac{2 K s \alpha \Theta^{2}}{r E}
\end{aligned}
$$

The solution to this is:

$$
F=\left(\frac{\beta}{2}\right)^{1 / 2} t^{-1 / 2}
$$

Substituting into equation (1)

$$
\begin{array}{r}
a=\left(\frac{\beta}{2}\right)^{1 / 2} \frac{1}{\Theta}=\left(\frac{K s \alpha}{r E}\right)^{1 / 2} \\
\text { also } \\
n=\frac{1}{2}
\end{array}
$$

\section{Applying the model to the Covercrete Absorption Test}

In this situation the area across which the water is flowing is approximately cylindrical (i.e. it is assumed that the section in fig. 4 has parallel sides). If the wetting front is a distance $\mathrm{x}$ 
from the centre of the drilled hole and the depth of the hole is 1 the area will be:

$$
\theta=2 \pi x l
$$

Substituting into equation (6) and integrating with respect to $x$

$$
\log (X)-\log \left(x_{0}\right)=\frac{2 \pi l k P}{F E}
$$

where $x_{0}$ is the radius of the drilled hole.

Combining with equation (4) and differentiating with respect to time:

$$
\begin{aligned}
\frac{d X^{2}}{d t} & =x_{0}^{2} \frac{d}{d t} e^{8 / F} \\
\text { where }: & \\
\delta & =\frac{8 \pi l K S}{r E}
\end{aligned}
$$

The volume of concrete inside the wetting front will be:

$$
V=\pi X^{2} l-V_{0}
$$

where $V_{0}$ is the volume of the drilled hole

Combining with equation (5) and (15) this gives:

$$
\begin{aligned}
& F=\frac{d}{d t} \gamma e^{\delta / F} \\
& \text { where }: \\
& \gamma=\alpha \pi l x_{o}^{2}
\end{aligned}
$$


the solution to this is:

$$
t=\frac{\gamma}{\delta} e^{\delta / F}\left(\frac{\delta}{F}-1\right)+\frac{\gamma}{\delta}
$$

For an approximate solution the exponential may be expanded as the initial terms of a power series:

$$
e^{\delta / F} \approx 1+\frac{\delta}{F}+\frac{\delta^{2}}{2 F^{2}}
$$

substituting and rearranging gives:

$$
t=\frac{\gamma \delta}{2 F^{2}}+\frac{\gamma \delta^{2}}{2 F^{3}}
$$

During the initial part of a test when $t$ is small $\delta / F$ will be $\approx 0$ and the last term may be omitted. This solution may be seen to be the same as the one dimensional solution in equation (11) with an area of $2 \pi \mathrm{x}_{0} \mathrm{l}$ (the area of the curved surface of the drilled hole).

\section{Results for the model}

The solutions given in equations (11) and (20) have been compared with the experimental results in Tabie (2) plotted from equation (1). The results are in figs 5,6,7 and 8 which show flow per unit area plotted against time. For the CAT results this area is the area of the curved surface of the drilled hole which has been used by previous workers (Dhir et.al. 1987).

These figures were obtained in the following way: 
The fixed parameters are as follows:

At $20^{\circ} \mathrm{C}$ the viscosity of water $\mathrm{E}=10^{-3} \mathrm{~Pa} \mathrm{~s}$ and

The surface tension of water $\mathrm{s}=0.073 \mathrm{~N} / \mathrm{m}$.

The area under the ISAT cap $\Theta=5.8 \times 10^{-3} \mathrm{~m}$

The depth of the drilled hole for CAT, $1=0.05 \mathrm{~m}$ and the radius, $x_{0}$ is $6.5 \times 10^{-3} \mathrm{~m}$.

The other variables are the pore radius and the porosity. The values used for these are given in Table 3. The flow rate depends on the ratio of the two and neither was measured so a constant porosity of $7 \%$ has been assumed which is typical for concrete (Claisse 1988). The different values for pore radius were set to give agreement with the model for the ISAT test. The pore radii obtained in this way are at the upper end of the range of pore sizes found in concrete. This is consistent with the assumptions of the model because if the radius of a pore varies along its length the capillary suction pressure to draw water along it will correspond to the largest radius. It may be seen that the model gives a lower pore radius for the Low Water Concrete and for the better curing condition (E1). This is consistent with previous work (Claisse 1988) but the extent of the difference will clearly be affected by the inaccurate assumption of constant porosity.

It may be seen that the model gives a far more accurate prediction of the difference between ISAT and CAT for the water cured samples. The reason for this is not known but it is unlikely that different fundamental processes are responsible because all of the samples were dried before testing.

\section{CONCLUSION}

Surface absorption tests on concrete samples have been modeled using the basic equations for capillary suction and permeability and the results show good agreement with experimental 
data. The higher results obtained from the CAT experiment relative to the ISAT have been explained.

\section{APPENDIX 1: REFERENCES}

Basheer P A M, Montgomery F R and Long A E., 1993, The "Autoclam Permeability System" for Measuring the In-Situ Permeation Properties of Concrete. Conference Proceedings of the British Institute of Non-Destructive Testing, 14-16 April, the University of Liverpool, UK, pp. 235-259.

BS 1881: Part 5 (1970) Methods of Testing Hardened Concrete for Other than Strength. British Standards Institute, London, UK.

Bungey J H., 1989, The testing of Concrete in Structures. Surrey University Press, London, UK, pp.137-161.

Claisse P A, 1988, Properties and performance of high strength Silica Fume Concrete, PhD Thesis, University of Leeds, UK.

Concrete Society., 1984, Development in Testing Concrete for Durability. Proceedings of One-Day Symposium, London, UK, 26 September, pp. 59-64.

Darcy (1856), Les fontaines publiques de la ville de Dijon, Paris, France.

Dhir R K, Hewlett P C and Chan Y N., 1987, Near Surface Characteristics of 
Concrete: assessment and development of in-situ test methods. Magazine of Concrete Research, Thomas Telford, London, UK, Vol. 39, No. 141, pp. 183-195.

Dhir R K and Byars E A., 1991, P F A Concrete: near surface absorption property. Magazine of Concrete Research, Thomas Telford, London, UK, Vol. 43, No, 157, pp. 219-232.

Hall C., 1989, Water Sorptivity of Mortars and Concretes: a review. Magazine of Concrete Research, Thomas Telford, London, UK, Vol, 41, No. 147, pp. 51-61.

Levitt M., 1969. Non-Destructive Testing of Concrete by the Initial Surface Absorption Method. Proceedings of Symposium on Non-Destructive Testing of concrete and Timber, Institute of Civil Engineers, London, UK, pp. 23-36.

Price W F and Bamforth P B., 1993, Initial Surface Absorption of Concrete: examination of modified test apparatus for obtaining uniaxial absorption. Magazine of Concrete Research, Thomas Telford, London, UK, Vol. 456, No. 162, pp. 17-24.

$$
\begin{aligned}
& \text { APPENDIX 2: NOTATION } \\
& \begin{array}{ll}
\text { a } & =\text { regression parameter dependant on concrete quality. } \\
\mathrm{E} & =\text { viscosity of the water }(\mathrm{Pa} \mathrm{s}) \\
\mathrm{F} & =\text { flow rate }\left(\mathrm{m}^{3} / \mathrm{s}\right) \\
\text { ISA } & =\text { initial surface absorption }\left(\mathrm{m}^{3} / \mathrm{m}^{2} / \mathrm{s}\right) \\
\mathrm{K} & =\quad \text { intrinsic permeability }\left(\mathrm{m}^{2}\right)
\end{array}
\end{aligned}
$$




$$
\begin{aligned}
& 1=\text { depth of drilled hole }(\mathrm{m}) \\
& \mathrm{n} \quad=\quad \text { regression parameter. } \\
& \mathrm{P} \quad=\quad \text { total pressure } \mathrm{drop}(\mathrm{Pa}) \\
& \mathrm{p}=\text { pressure at a distance } \mathrm{x} \text { from the water reservoir }(\mathrm{Pa}) \text {. } \\
& \mathrm{r}=\text { radius of the pores }(\mathrm{m}) \\
& S=\text { sorptivity } \\
& \mathrm{s}=\quad \text { surface tension of the water }(\mathrm{N} / \mathrm{m}) \\
& \mathrm{t}=\text { absorption time (s). } \\
& \mathrm{V}=\text { saturated volume }\left(\mathrm{m}^{3}\right) \\
& V_{0}=\text { volume of drilled hole }\left(\mathrm{m}^{3}\right) \\
& \mathrm{x}=\operatorname{distance}(\mathrm{m}) \\
& \mathrm{x}_{0}=\text { radius of drilled hole } \\
& \mathrm{X}=\text { distance from the reservoir to the wetting front }(\mathrm{m}) \text {. } \\
& \alpha=\text { porosity } \\
& \beta=\frac{2 K s \alpha \Theta^{2}}{r E} \\
& \gamma \quad=\alpha \pi l x_{o}^{2} \\
& \delta=\frac{8 \pi l K s}{r E} \\
& \theta=\text { area across which the water is flowing }\left(\mathrm{m}^{2}\right) \text {. } \\
& \Theta \quad=\quad \text { constant area }\left(\mathrm{m}^{2}\right)
\end{aligned}
$$


Table 1: $\quad$ Concrete mix proportions for grade 35 concretes

\begin{tabular}{|c|c|c|c|c|c|c|c|}
\hline \multirow{3}{*}{$\begin{array}{c}\text { CONCRETE } \\
\text { TYPE }\end{array}$} & \multicolumn{5}{|c|}{ CONSTITUENT MATERIALS, Kg/m3 } & \multirow{3}{*}{$\mathrm{W} / \mathrm{C}$} & ADMIXTURE \\
\hline & \multirow[b]{2}{*}{$\mathrm{OPC}$} & \multirow[b]{2}{*}{ Water } & \multicolumn{3}{|c|}{ Aggregates } & & $\%$ CEMENT \\
\hline & & & $20 \mathrm{~mm}$ & $10 \mathrm{~mm}$ & Sand & & SP \\
\hline $\mathrm{OPC}$ & 290 & 190 & 800 & 400 & 715 & 0.66 & -- \\
\hline LWC & 240 & 160 & 840 & 410 & 745 & 0.66 & 2.6 \\
\hline
\end{tabular}


Table 2 Experimental results

\begin{tabular}{|l|l|l|l|l|l|l|l|l|}
\hline Mix & Curing & \multicolumn{2}{|l|}{ ISAT } & \multicolumn{2}{|l|}{ Sorption } & \multicolumn{2}{l|}{ CAT } & Permeability \\
\hline & & $\mathrm{a} \times 10^{-6}$ & $\mathrm{n}$ & $\mathrm{a} \times 10^{-6}$ & $\mathrm{n}$ & $\mathrm{a} \times 10^{-6}$ & $\mathrm{n}$ & $\mathrm{m}^{2} \times 10^{-17}$ \\
\hline OPC & $\mathrm{E} 1$ & 6.11 & 0.38 & 6.98 & 0.40 & 4.64 & 0.22 & 2.7 \\
\hline OPC & $\mathrm{E} 2$ & 13.95 & 0.40 & 14.26 & 0.40 & 8.53 & 0.24 & 33 \\
\hline LWC & E1 & 5.40 & 0.39 & 4.83 & 0.38 & 4.43 & 0.24 & 0.4 \\
\hline LWC & E2 & 9.28 & 0.40 & 7.96 & 0.38 & 6.79 & 0.27 & 2.0 \\
\hline
\end{tabular}


Table 3 Parameters for the model

\begin{tabular}{||l|l|l|l|}
\hline \hline Mix & Curing & Porosity & Pore radius \\
\hline & & $\alpha \%$ & $\mathrm{r} \mu \mathrm{m}$ \\
\hline OPC & E1 & 7 & 0.6 \\
\hline OPC & E2 & 7 & 2 \\
\hline LWC & E1 & 7 & 0.12 \\
\hline LWC & E2 & 7 & 0.3 \\
\hline
\end{tabular}




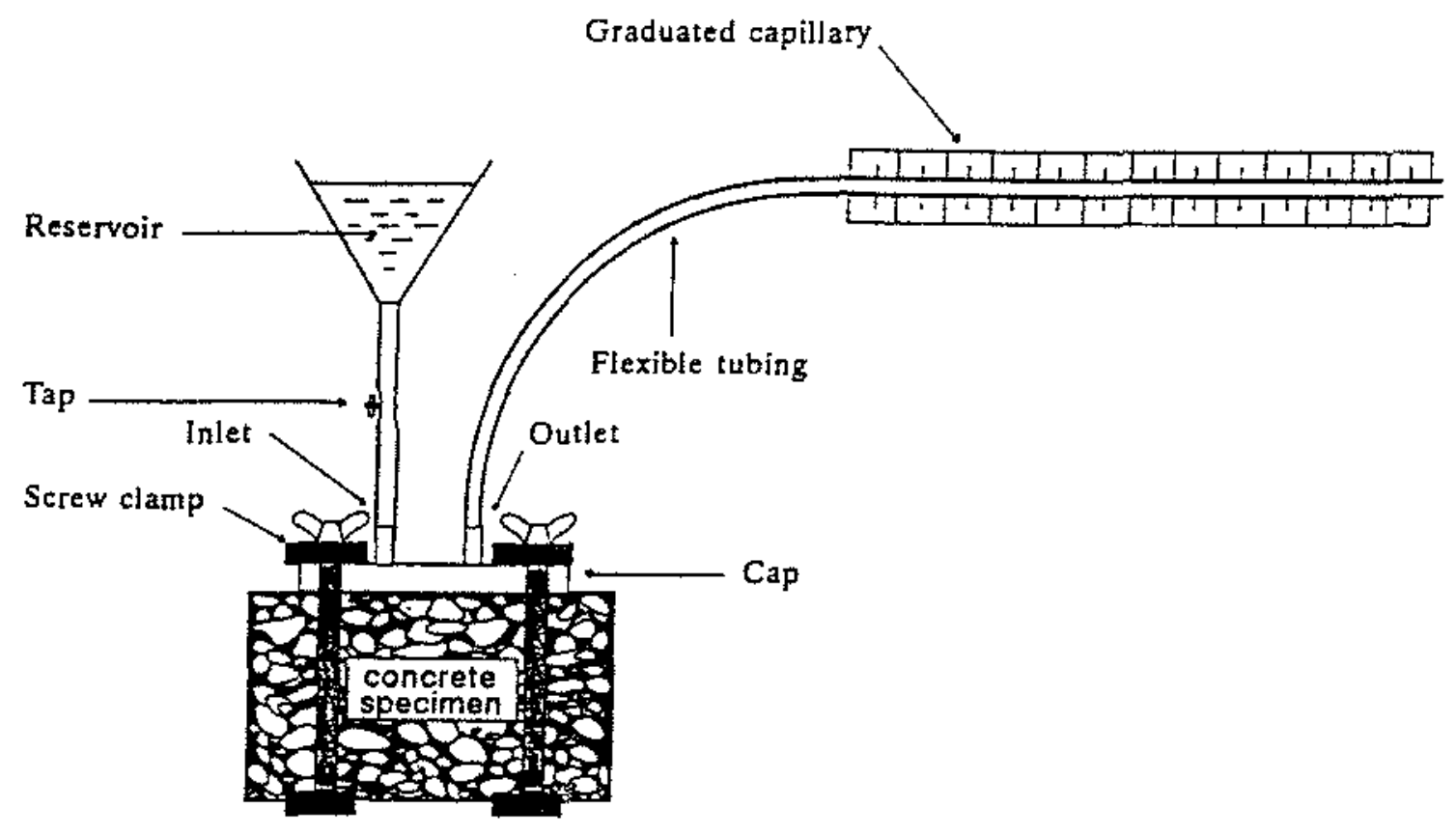

Schematic arrangement of ISAT

Figure 1 


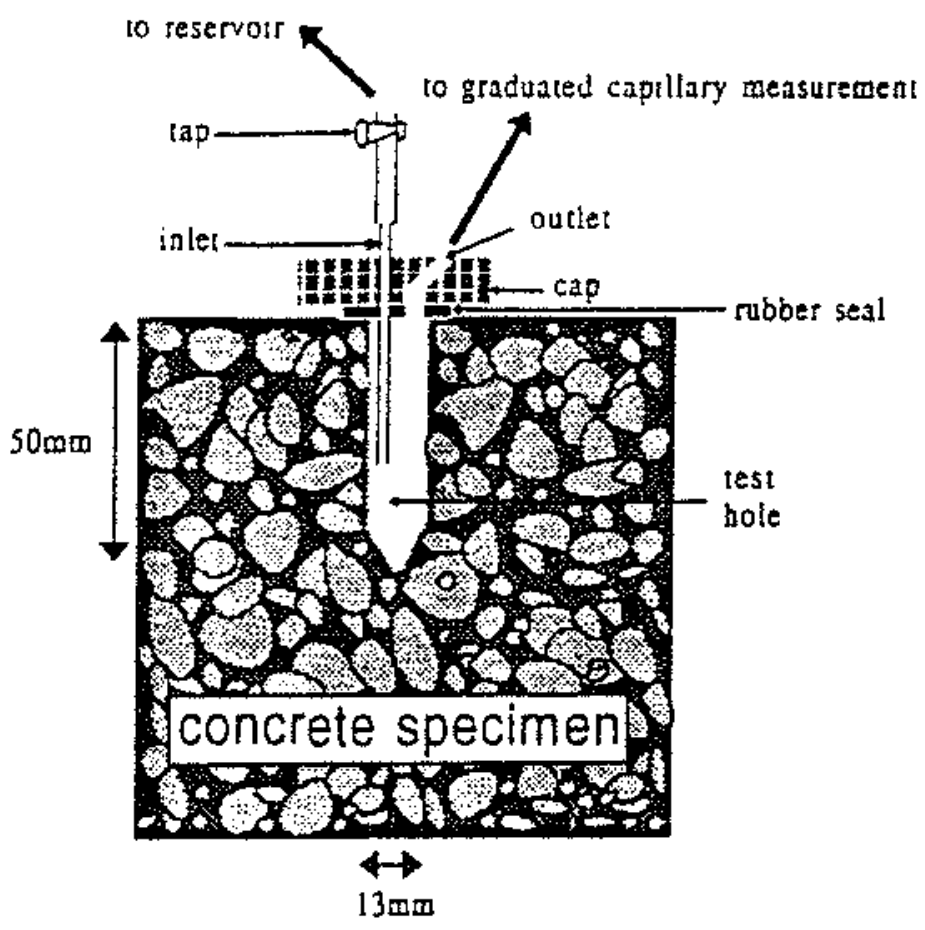

Schematic arrangement of CAT

Figure 2 


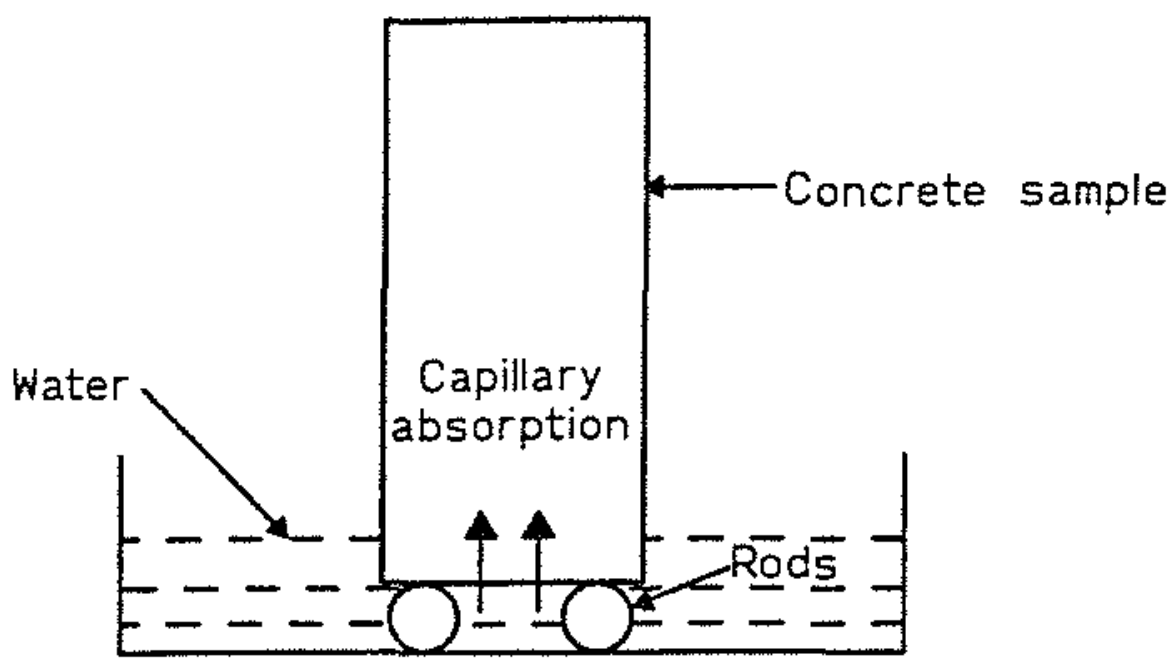

Schematic diagram for the sorptivity test

Figure 3 


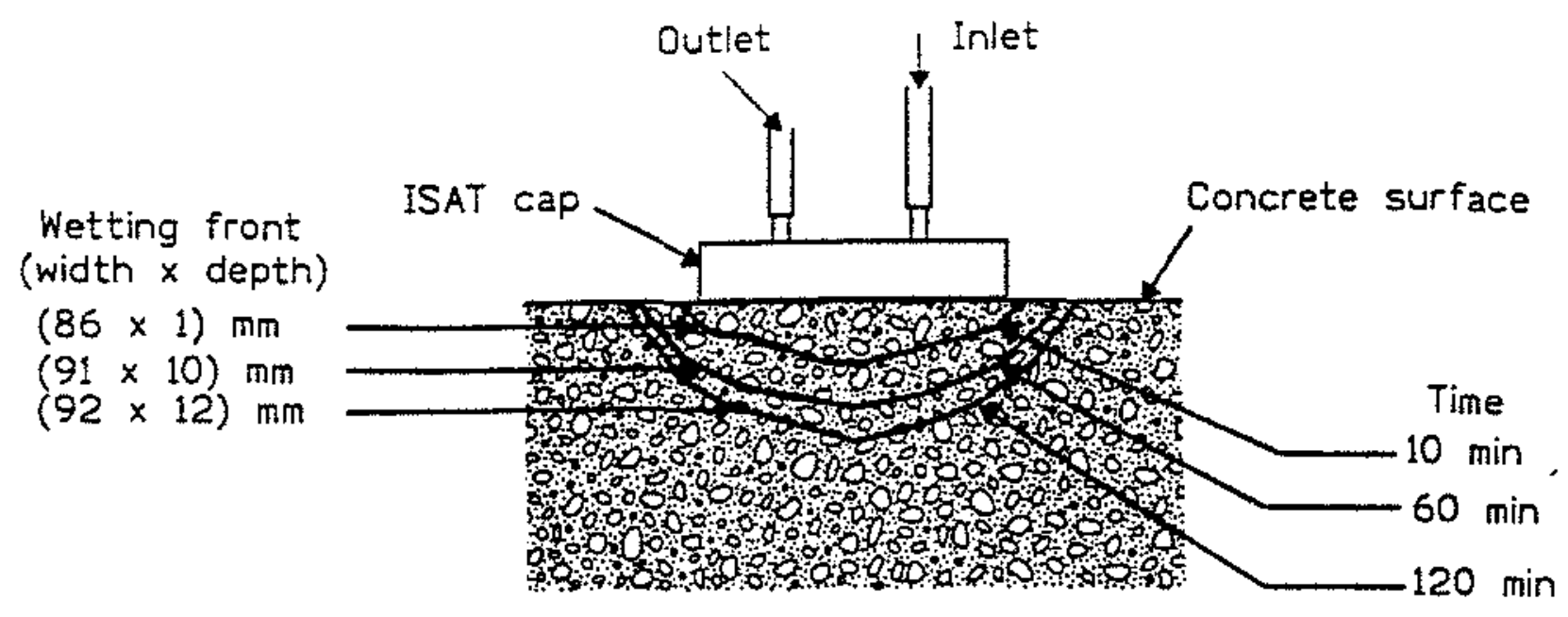

(a) ISAT (circular source of flow)

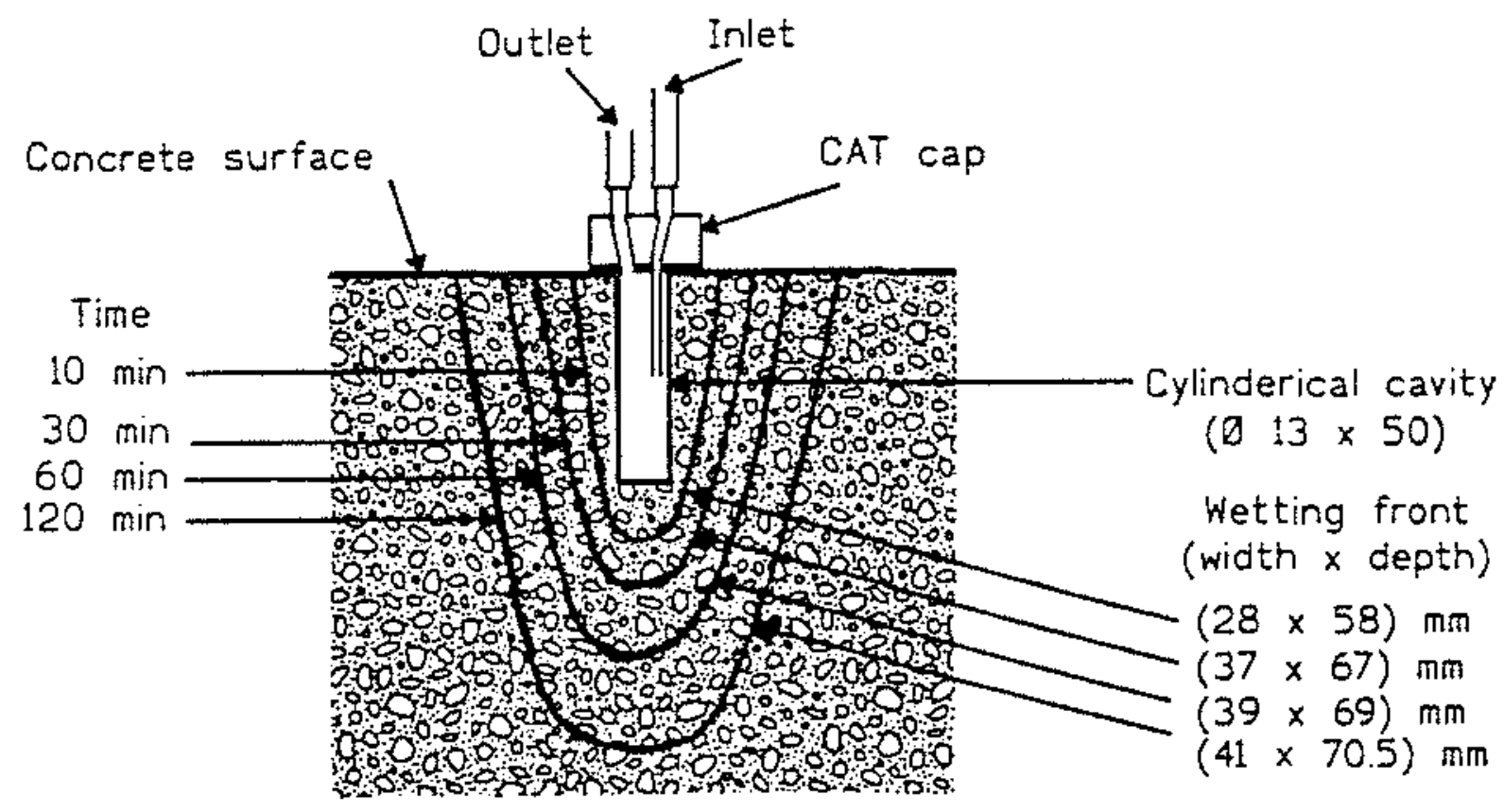

(b) CAT (cylinderical source of flow)

Typical wetting front profiles during ISAT and CAT runs for grade 35 water cured concrete

Figure 4 
Mix OPC Curing:\$1

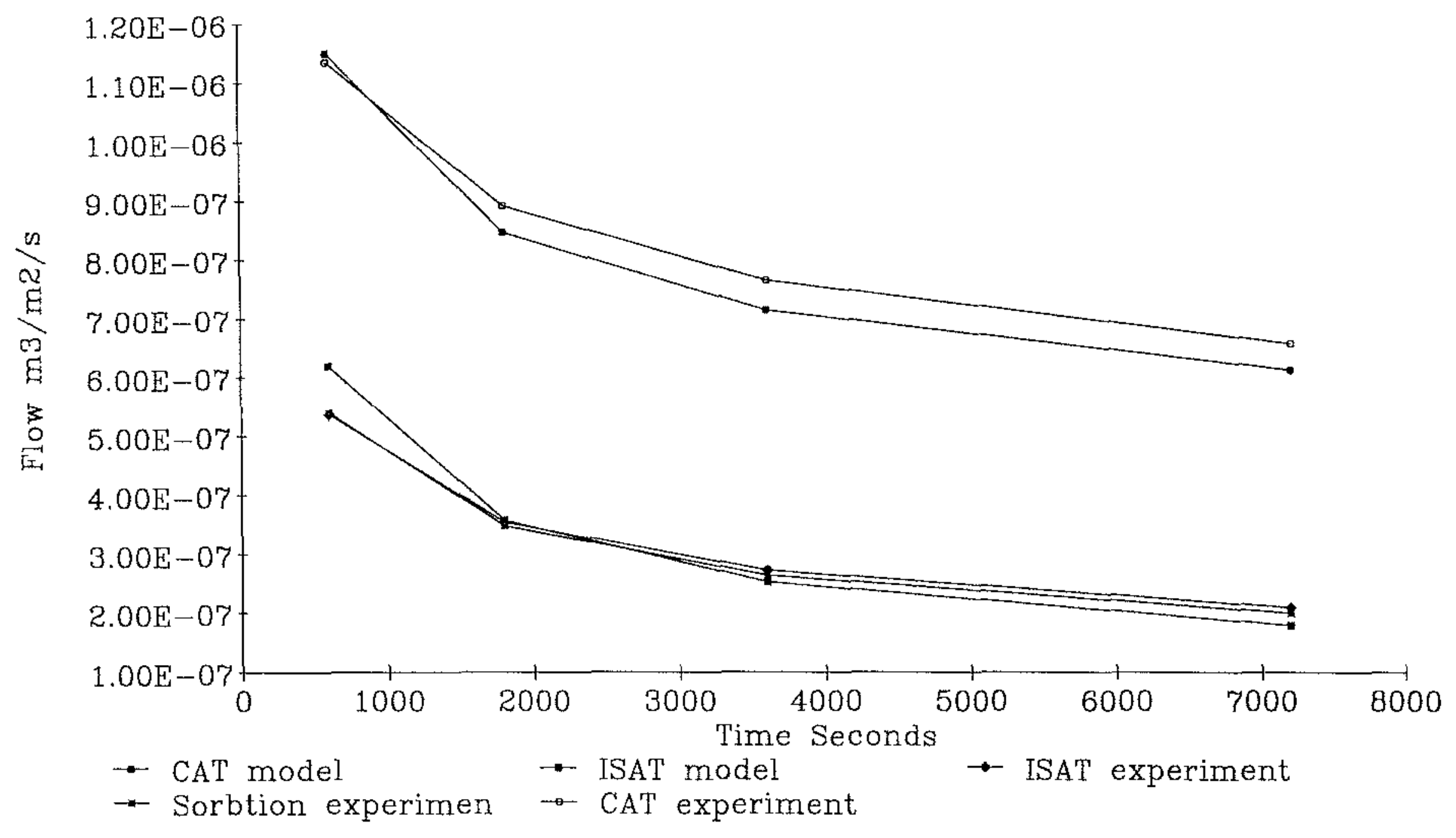

Figure 5 


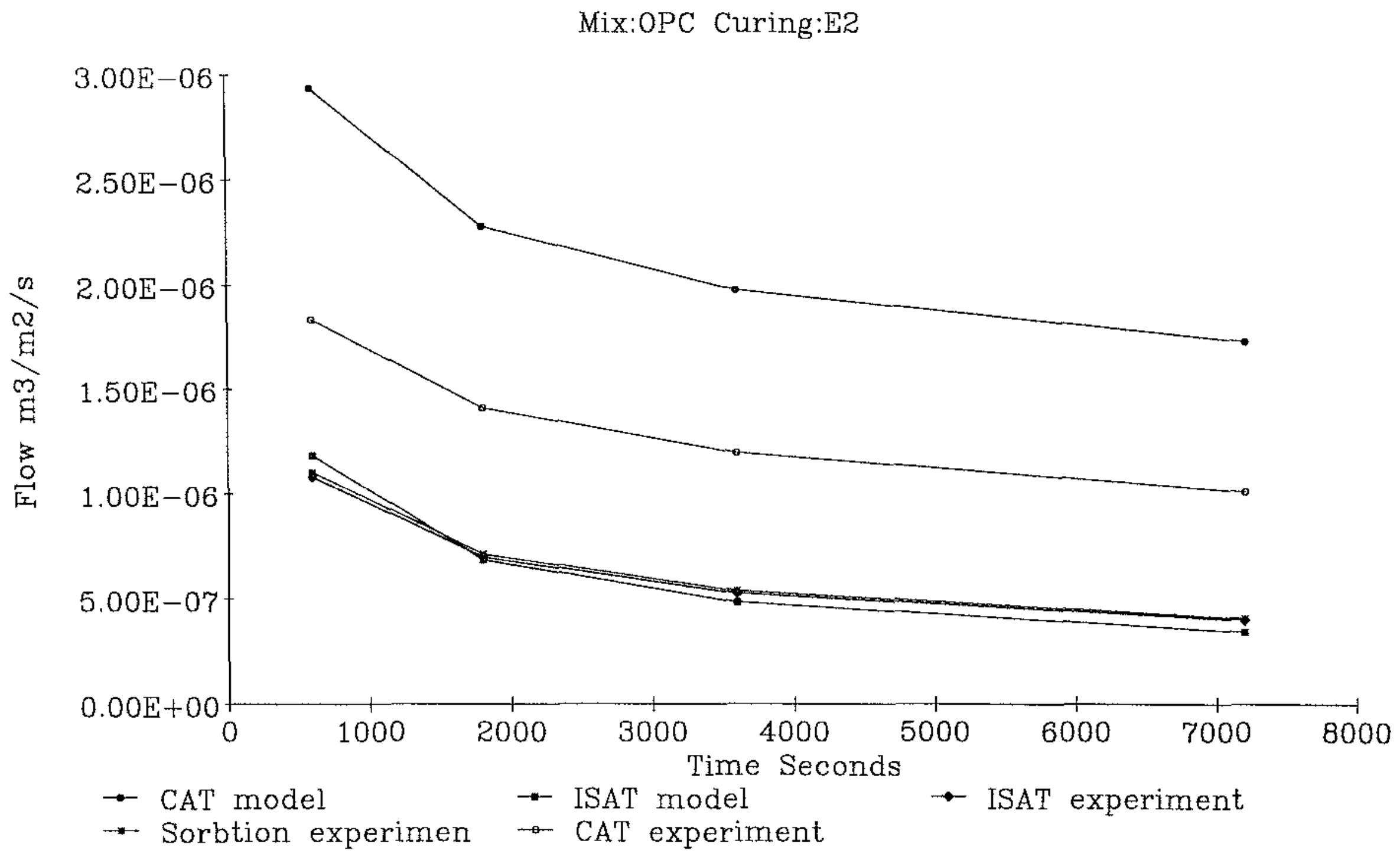

Figure 6 
Mix:LWC Curing:E1

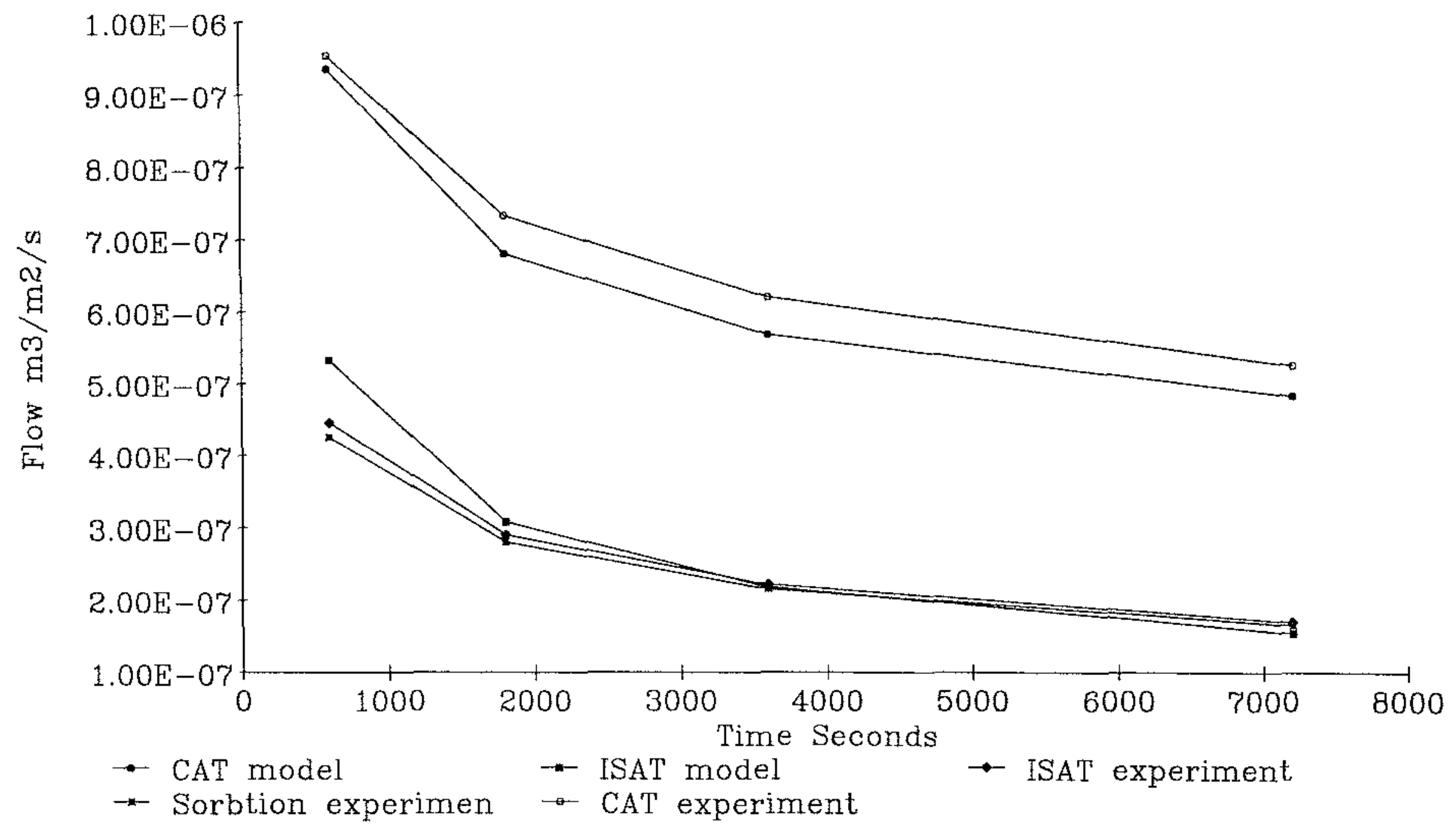

Figure 7 


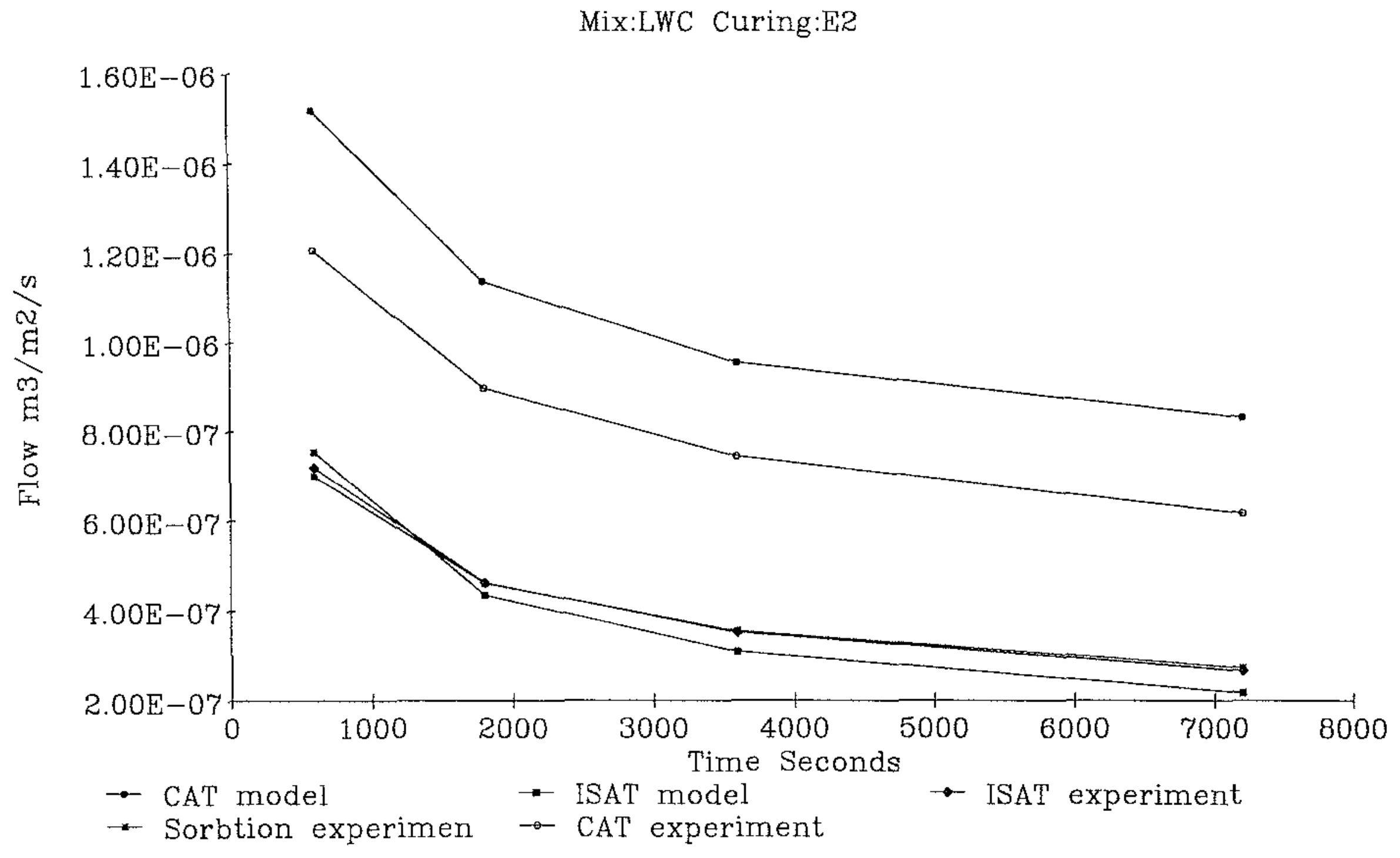

Figure 8 